\title{
Progenitor Cell Therapy to Treat Acute Myocardial Infarction: The Promise of High-Dose Autologous $\mathrm{CD}^{+}{ }^{+}$Bone Marrow Mononuclear Cells
}

\author{
Joseph C. Poole ${ }^{1}$ and Arshed A. Quyyumi ${ }^{1,2}$ \\ ${ }^{1}$ Emory University School of Medicine, Division of Cardiology, 319 Woodruff Memorial Research Building, \\ 1639 Pierce Drive, Suite 319, Atlanta, GA 30322, USA \\ ${ }^{2}$ Emory Clinical Cardiovascular Research Institute, 1462 Clifton Road NE, Suite 506, \\ Atlanta, GA 30322, USA \\ Correspondence should be addressed to Arshed A. Quyyumi; aquyyum@emory.edu
}

Received 19 October 2012; Revised 18 March 2013; Accepted 21 March 2013

Academic Editor: Leonard M. Eisenberg

Copyright (C) 2013 J. C. Poole and A. A. Quyyumi. This is an open access article distributed under the Creative Commons Attribution License, which permits unrestricted use, distribution, and reproduction in any medium, provided the original work is properly cited.

\begin{abstract}
ST elevation myocardial infarction (STEMI) is associated with an increased risk for congestive heart failure and long-term mortality despite the widespread use of thrombolysis and catheter-based revascularization. The need for improved post-STEMI therapies has led to a surge of novel therapeutics, especially regenerative approaches using autologous mononuclear cells. Indeed, the past decade has been marked by a number of human trials studying the safety and efficacy of progenitor cell delivery in the post-STEMI setting. While a variety of cell types and delivery techniques have been utilized, directed therapy to the infarct-related artery has been the most widely used approach. From over 1300 subjects randomized in these studies, there is sufficient evidence to conclude that cell therapy after STEMI is uniformly safe, while the efficacy of this intervention for improving outcomes is less clear. Recent metaanalyses have highlighted the importance of both timing of cell delivery, as well as the type, quantity, and mobility of delivered cells as determinants of response. Here, we show the case in which higher doses of CD $34^{+}$cells, which are more potent in terms of their migratory capacity, offer the best hope for preserving cardiac function following STEMI.
\end{abstract}

\section{Introduction}

Despite early thrombolysis and revascularization, ST elevation myocardial infarction (STEMI) carries significant morbidity and mortality $[1,2]$. Following acute STEMI, failure of prompt revascularization leads to myocardial necrosis that can cause ventricular chamber dilation through adverse remodeling, often leaving patients with permanent left ventricular (LV) systolic dysfunction and progressive congestive heart failure $[3,4]$. Optimal medical therapy and cardiac rehabilitation in the postinfarct period helps minimize adverse remodeling; however, 12-month mortality for patients with STEMI and LV dysfunction still exceeds 10\% [5].

In a landmark preclinical study, Orlic et al. demonstrated that direct injection into the infarcted myocardium of a highly defined bone marrow derived-cell ( $\mathrm{Lin}^{-} \mathrm{c}-\mathrm{kit}^{\mathrm{pos}}$ ) population with hematopoietic and endothelial progenitor potential improved morbidity and mortality in a murine MI model. Within 3-5 hours of an induced anterior MI, mice received either $\mathrm{Lin}^{-} \mathrm{c}$-kit ${ }^{\text {pos }}$ cells, $\mathrm{Lin}^{+}$cells, or no injection. In animals receiving $\mathrm{Lin}^{-} \mathrm{c}^{-\mathrm{kit}^{\mathrm{pos}}}$ cells, more than twothirds of the infarcted myocardium was repopulated with regenerated myocytes; there was clear neovascularization, and cardiac function improved.

The need for improved postinfarct therapies, together with the promise of regenerative medicine, has spawned a surge in human trials studying the safety and efficacy of progenitor cell delivery in the post-STEMI setting. While a variety of cell types and delivery techniques (intravenous, direct myocardial injection, nonspecific bone marrow stimulation and intra-arterial) have been utilized in the postacute MI setting, the majority of studies have used a percutaneous 
TABLE 1: Clinical trials of bone marrow cell (BMC) therapy by intracoronary delivery following acute ST-segment elevation MI (STEMI).

\begin{tabular}{|c|c|c|c|c|c|}
\hline $\begin{array}{l}\text { Study author } \\
\text { (trial name) }\end{array}$ & Date published & $N$ & $\begin{array}{l}\text { Days after STEMI } \\
\text { (mean) }\end{array}$ & Primary outcome & $\begin{array}{c}\text { Mean no. CD34 }{ }^{+} \text {cells } \\
\text { (millions) }\end{array}$ \\
\hline $\begin{array}{l}\text { Assmus et al., [10] } \\
\text { (TOPCARE-AMI) }\end{array}$ & 2002 & 20 & 4 & Improved LVEF & 7.4 \\
\hline Fernandez-Aviles et al., [46] & 2004 & 20 & 13 & No difference & Not reported \\
\hline Bartunek et al., [55] & 2005 & 35 & 11.6 & Improved LVEF & 15.4 \\
\hline $\begin{array}{l}\text { Ge et al., [15] } \\
\text { (TCT-STAMI) }\end{array}$ & 2006 & 20 & $<1$ & Improved LVEF & 0.1 \\
\hline $\begin{array}{l}\text { Hirsch et al., [19] } \\
\text { (HEBE) }\end{array}$ & 2011 & 200 & 5 & No difference & 4 \\
\hline $\begin{array}{l}\text { Huikuri et al., [16] } \\
\text { (FINCELL) }\end{array}$ & 2008 & 80 & 3 & Improved LVEF & 2.6 \\
\hline $\begin{array}{l}\text { Janssens et al., [20] } \\
\text { (LEUVEN-AMI) }\end{array}$ & 2006 & 67 & $<1$ & No difference & 2.8 \\
\hline $\begin{array}{l}\text { Lunde et al., [21] } \\
\text { (ASTAMI) }\end{array}$ & 2006 & 97 & 6 & No difference & 0.7 \\
\hline Meluzín et al., [50] & 2008 & 60 & 6.9 & Improved LVEF & Not reported \\
\hline $\begin{array}{l}\text { Quyyumi et al., [39] } \\
\text { (AMR-001) }\end{array}$ & 2011 & 31 & 8 & $\begin{array}{l}\text { Positive trend towards improved } \\
\text { EF in highest dose group }\end{array}$ & $5,10,15$ \\
\hline Roncalli et al., [56] & 2011 & 101 & 9.3 & Improved myocardial viability & 1.2 \\
\hline $\begin{array}{l}\text { Schachinger et al., [17] } \\
\text { (REPAIR-AMI) }\end{array}$ & 2006 & 204 & 4 & Improved LVEF & 3.6 \\
\hline Strauer et al., [6] & 2002 & 10 & 7 & No difference & $<0.6$ \\
\hline $\begin{array}{l}\text { Tendera et al., [25] } \\
\text { (REGENT) }\end{array}$ & 2009 & 200 & 7 & No difference & $\begin{array}{l}1.9\left(\mathrm{CD} 34^{+} \mathrm{CXCR}^{+} \text {cell }\right. \\
\text { group), not reported for } \\
\text { unselected cell group }\end{array}$ \\
\hline Traverse et al., [23] & 2010 & 40 & 5 & No difference & 1.6 \\
\hline $\begin{array}{l}\text { Traverse et al., [22] } \\
\text { (LateTIME) }\end{array}$ & 2011 & 87 & 17 & No difference & 3.8 \\
\hline $\begin{array}{l}\text { Wollert et al., [13] } \\
\text { (BOOST) }\end{array}$ & 2004 & 60 & 5 & Improved LVEF & 9.5 \\
\hline
\end{tabular}

catheter-based approach to direct therapy to the coronary artery. To date, at least 17 randomized controlled trials (RCTs) have investigated infarct-related artery (IRA) infusion of bone marrow-derived mononuclear cells (BMMNCs) using the "stop-flow technique" [6] following acute STEMI (Table 1). From more than 1300 subjects randomized in these studies, there is sufficient evidence to conclude that cell therapy after STEMI is uniformly safe, while the efficacy of this intervention in improving left ventricular ejection fraction (LVEF) and major adverse cardiovascular events (MACEs) has been less clear. Subgroup analyses in recent meta-analyses have highlighted the importance of both timing of cell delivery, and the type, quantity, and mobility of delivered cells as determinants of response and specifically suggest that higher doses of $\mathrm{CD} 34^{+}$cells that are potent in terms of their migratory capacity offer the best hope for preserving cardiac function following STEMI [7-9].

\section{Autologous Progenitor Cell Therapy after STEMI}

The transplantation of progenitor cells and regeneration enhancement in acute myocardial infarction (TOPCARE-AMI) trial was the first randomized controlled trial (RCT) to demonstrate functional improvement by BMMNCs following STEMI [10]. In total, 59 subjects were enrolled in TOPCAREAMI, 29 receiving BMMNCs, and 30 subjects receiving circulating mononuclear cells. Cells were delivered to the infarct-related artery at $4.9 \pm 1.5$ days after STEMI. At a mean followup of 4 months, LVEF improved in the BMMNC group from $49 \pm 10 \%$ to $57 \pm 10 \%(P<0.001)$ and from $51 \pm 10 \%$ to $59 \pm 10 \%(P<0.001)$ in the group receiving circulating progenitor cells. Subsequent followup indicated long-term safety of the therapy at 1 [11] and 5 years [12]. In a combined analysis of 55 subjects available for 5 -year followup, LVEF by cardiac magnetic resonance imaging improved from $46 \pm 10 \%$ to $57 \pm 10 \%(P<0.001)$ and functional infarct size similarly improved as measured by late enhancement volume normalized to $\mathrm{LV}$ mass $(P<0.001)$.

In the Bone marrow transfer to enhance ST-elevation infarct regeneration (BOOST) trial, the efficacy of autologous BMMNCs delivered to infarct-related artery was evaluated in 60 patients $4.8 \pm 1.3$ days after STEMI [13]. In distinction to TOPCARE-AMI, the control group in the BOOST trial received optimum postinfarction medical therapy, but no cells. At 6-month followup, mean LVEF improved by $6.7 \%$ 
in the cell therapy group (from $46.3 \pm 10.6 \%$ to $53 \pm 15.5 \%$ ) and by $1.1 \%$ in the control group (from $47.8 \pm 9.7 \%$ to $48.9 \pm 15.2 \%)(P$ value for between-group comparison $=0.04)$. Long-term followup of surviving subjects at 5 years $(N=56$; mean followup $61 \pm 11$ months) revealed no difference in cardiac function or MACE between groups. LVEF assessed by magnetic resonance imaging decreased by $3.3 \pm 9.5 \%$ in the control group and by $2.5 \pm 11.9 \%$ in the group that received BMMNCs $(P=0.30)[14]$.

To date, three other studies comparing autologous BMMNCs to a placebo control have reported positive results [1517]. The Reinfusion of Enriched Progenitor Cells and Infarct Remodeling in Acute Myocardial Infarction (REPAIR-AMI) trial is the largest trial to date to evaluate the efficacy of BMMNCs in the post-STEMI setting [17]. This multicenter trial randomized 204 subjects to receive either BMMNCs or placebo medium, from 3 to 7 days after STEMI. At 4-month followup, LVEF improved by $5.5 \pm 7.3 \%$ in the treatment group and by $3.0 \pm 6.5 \%$ in the placebo group $(P=0.01$ between groups). At 2 years, the occurrence of MACE was significantly lower in the cell therapy group (28\%) compared to placebo group (43\%) $(P=0.025)$ [18]. The Finish stem cell study (FINCELL) randomized 80 subjects to receive intracoronary autologous BMCs or placebo media at 2-6 days after STEMI [16]. At six months of followup, the BMC treatment group had significant improvement in LVEF by transthoracic echocardiogram compared to the placebo group $(4.0 \pm 11.2$ versus $-1.4 \pm 10.2 \% ; P=0.03)$. No differences in MACE at 6 months between groups were reported. Ge et al. reported similar findings in a smaller study $(N=20)$ in which the treatment group received autologous BMMNCs 12 hours after diagnosis of STEMI [15]. In the 10 subjects who received cells, LVEF improved at 6-month followup from $53.8 \pm 9.2$ to $58.6 \pm 9.9 ; P<0.05$, but remained unchanged in the placebo group. The potential impacts of myocardial stunning in the immediate post-STEMI period (when cells were delivered), the small number of subjects randomized, and the relatively preserved LVEF immediately after STEMI make this study more difficult to interpret compared to REPAIR-AMI and FINCELL.

Positive trials comparing autologous BMMNCs to placebo have been encouraging, but they must be interpreted with caution given that many trials have reported neutral findings [19-23]. Among these negative trials is the recently concluded LateTIME study that evaluated the efficacy of delaying delivery of autologous BMMNCs 2-3 weeks following STEMI [22]. The LateTIME trial was a multicenter US trial performed by the National Heart, Lung, and Blood Institute-sponsored Cardiovascular Cell therapy Research Network. Rationale for testing the benefit of later cell delivery was both practical and evidence based. Most patients with STEMI present to centers lacking expertise in cell therapy, and several trials have demonstrated that cell therapy preferentially benefits patients with lower $\operatorname{LVEF}[17,24,25]$ who may be too sick or unstable to tolerate bone marrow aspiration and cell delivery in the first few days following STEMI. A total of 87 patients were randomized to receive either autologous BMCs or placebo. At 6-month followup, there was no significant difference between treatment and placebo arms for either primary (changes in LVEF and regional wall motion in the infarct and border zones) or secondary outcomes (changes in LV volumes and infarct size).

\section{Justification for Using Purified Cells with Increased Regenerative Potential}

Given disparate findings from a decade of RCTs, the efficacy of intracoronary infusion of autologous BMMNCs has been evaluated by several meta-analyses [7-9]. These analyses demonstrate that BMMNC therapy is safe and associated with modest improvement in LVEF (3.66\% absolute improvement), reduction in infarct scar size $(-5.49 \%)$, and reduction in LVESV $(-4.80 \mathrm{~mL})$. Subjects receiving BMMNCs had a significant reduction in recurrent $\mathrm{MI}(P=0.04)$ and trends toward improved mortality, repeat revascularization, and heart failure hospitalizations. When subset analyses were performed, it appeared that improvement in LVEF was more likely among patients with (1) lower baseline LVEF, (2) those in whom cells were infused during the repair phase (days 57 after STEMI), (3) in those receiving $>10^{8}$ BMMNCs, and (4) cells prepared without heparin as it appears to reduce function of SDF-1 [26].

The composition of mononuclear cells by cell subtype and cell potency may also be important predictors of efficacy. CD34 ${ }^{+}$expressing BMMNCs are enriched for hematopoietic and (to a lesser degree) endothelial progenitor cells and have been shown experimentally to localize more avidly in the peri-infarct zone than unselected mononuclear cells not expressing $\mathrm{CD}^{+} 4^{+}$epitope [27]. Using radio-labeled cells, it has been demonstrated that a greater proportion of CD $34^{+}$cells home to peri-infarct zones after intracoronary delivery than undifferentiated BMMNCs [27, 28]. Further, the biologic potency measured as mobility of cells coexpressing CXCR-4 in a stromal derived factor-1 (SDF-1) gradient appears to be a crucial determinant of efficacy [25, 29-31]. Thus, the current shift in post-MI cell therapy field is towards delivering a highly selected and highly mobile progenitor cell product at a sufficient dose to maximize preservation of cardiac function.

CD34 is a novel hematopoietic progenitor cell antigen that is expressed in human bone marrow, blood, and fetal liver $[32,33]$. In vitro, CD $34^{+}$cells differentiate into endothelialand smooth muscle-like cells and form angiogenesis-like networks in Matrigel [34]. Originally considered the putative "endothelial progenitor cell" (EPC) [35], bone marrow CD $34^{+}$cells are a relatively uncommon cell type $(\sim 1-2 \%)$ in human bone marrow and are now known to transdifferentiate into hematopoietic lineage cells and rarely also into endothelial cells, smooth muscle cells, and cardiomyocytes in vivo [36]. CD34 antigen is expressed by immature endothelial cell precursors and appears to confer hematopoietic potential, especially in combination with CD133 [33]. In contrast, coexpression of CD34 and the vascular endothelial growth factor receptor-2 denotes a population enriched for endothelial progenitors [37].

Stamm et al. first attempted to utilize CD $34^{+}$cells in humans after MI [38]. In a study of six subjects with a history 
of MI, dual positive $\mathrm{CD} 34^{+} / \mathrm{CD} 133^{+}$cells were injected in the infarct border zone during coronary artery bypass grafting. On the day prior to surgery, subjects underwent a bone marrow harvest from the iliac crest. Marrow aspirate was isolated for mononuclear cell by ficoll density centrifugation followed by monoclonal antibody selection for $\mathrm{CD} 133^{+}$cells. These cells showed high purity for $\mathrm{CD} 34^{+}$and $\mathrm{CD} 133^{+}$ markers (75-90\%) and high viability (75-91\%). Cells were delivered in the operating room during CABG by direct myocardial injection prior to reperfusion. At six-month followup, all patients had improved perfusion by SPECT, and 4 of 6 patients had significantly improved LVEF and diastolic LV dimensions by transthoracic echocardiogram.

The prospect of delivering isolated $\mathrm{CD} 34^{+}$cells in favor of unselected cells for post-MI repair garnered attention from a study comparing human $\mathrm{CD} 34^{+}$cells to human total mononuclear cells in a nude rat MI model [30]. Animals receiving $\mathrm{CD} 34^{+}$cells had greater capillary density in the infarcted myocardium, lower percent fibrosis, and a significantly improved cardiac function at 28 days compared to their counterparts receiving unselected mononuclear cells.

The REGENT trial addressed the relative efficacy of $\mathrm{CD} 34^{+}$cells compared to unselected cells in humans after STEMI [25]. One hundred and sixty patients were randomized to receive either $1.8 \times 10^{8}$ unselected autologous BMMNCs, $1.9 \times 10^{6} \mathrm{CD} 34^{+} \mathrm{CXCR} 4^{+}$cells, or no cells 7 days following STEMI. The two treatment groups had absolute improvement in LVEF by $3 \%$ at 6 -month followup ( $P$ s < 0.05 ), while LVEF in the control group (no cells) did not change $(P=0.73)$. A greater proportion of patients receiving CD $34^{+}$CXCR $^{+}$cells improved LVEF at 6 months (51\%), compared to $39 \%$ of those receiving unselected cells and $36 \%$ for controls; however, this difference did not reach statistical significance. There was no significant difference in major adverse cardiovascular events (MACEs) between the groups at 6 months.

\section{AMR-001}

4.1. Hypothesis. We recently completed the first prospective, dose-escalation controlled trial to determine whether a CD $34^{+}$cell dose threshold for effect exists after acute STEMI [39]. We hypothesized that intracoronary autologous bone marrow-derived $\mathrm{CD}_{3} 4^{+}$cell infusion would be safe, and the therapeutic effect would be dose dependent.

4.2. Study Design. To determine the effective $\mathrm{CD} 34^{+}$cells cell dose threshold, we prospectively assessed the safety and efficacy of intracoronary infusion of autologous bone marrowderived $\mathrm{CD} 34^{+}$cells administered sequentially at three dose levels (5, 10, and 15 millions). Subjects with acute STEMI successfully treated with intracoronary stent implantation within three days of hospitalization were consented. Only patients with LVEF $\leq 50 \%$ by echocardiography and a regional wall motion abnormality in the distribution of the infarct related artery, four or more days after stenting, were enrolled. Subjects were enrolled randomly at each site as controls $(N=$ 15) to receive the standard of care or to the open label cell therapy group to receive one of three dose levels of CD34 ${ }^{+}$ cells $(5,10$, or 15 millions; $N=5$ in each group).

4.3. Methods. From five to eight days after coronary stenting, patients in the treatment group had a minibone marrow harvest using conscious sedation and local anesthesia. Harvested cells were transferred to a central GMP facility (Progenitor Cell Therap, Hackensack, NJ, USA) where CD $34^{+}$ cells were isolated and enriched using the anti-CD34 Mab and Dynabeads (Baxter, Deerfield, IL, USA) on the Isolex $300 \mathrm{i}$ system. $\mathrm{CD} 34^{+}$cell enumeration, purity, and viability were assayed by flow cytometry using anti-CD34/CD45 antibody and 7-AAD (Stem-Kit reagents, Beckman Coulter, Brea, CA, USA). Endotoxin levels were determined using Limulus Amebocyte Lysate Kinetic-QCL Test Kit (Lonza, Allendale, NJ, USA). Sterility was tested by 14 -day product culture in fluid thioglycollate medium and tryptic soy broth. Preliminary product sterility assessment was determined by gram staining. The final $\mathrm{CD} 34^{+}$cell product was formulated in $6 \mathrm{~mL}$ of Dulbecco's Phosphate Buffered Saline (Baxter) and $4 \mathrm{~mL}(40 \%)$ of autologous human serum containing $1 \%$ human serum albumin (Alpha) and 25 USP units $/ \mathrm{mL}$ of heparin sodium stored in a sterile $10 \mathrm{~mL}$ syringe. Selected CD $34^{+}$cells were aliquoted according to targeted doses and tested for coexpression of VEGFR- 2 and CXCR- 4 by flow cytometry and assessed in vitro for SDF-1 mobility and colony-forming unit-granulocyte-macrophage (CFUGM) growth as described elsewhere [6, 40]. The percentage of $\mathrm{CD} 34^{+}$cells within harvested bone marrow and $\mathrm{CD} 34^{+}$ cell mobility in an SDF-1 gradient was compared with and without autologous serum in age-matched healthy volunteers free from any symptomatic coronary artery disease $(N=$ $10)$ and patients participating in our trial $(N=6)$. $24-48$ hours after bone marrow harvest, treatment group subjects $(N=16)$ underwent repeat coronary angiography, and the cell product was infused via an over-the-wire balloon catheter positioned within the stented segment using a stop-flow technique described previously [6].

4.4. Results. Cell harvest and infusion were safe. Quantitative rest hypoperfusion score measured by SPECT improved at 6 months in subjects receiving $\geq 10$ million $\mathrm{CD} 34^{+}$cells compared with controls $(-256$ versus $+14 ; P=0.02)$. There was a trend toward improvement of ejection fraction $(+4.5 \%$, $P=0.059$ compared to baseline) in the high-dose groups compared to no change in controls and those receiving 5 million CD $34^{+}$cells $(+0.7 \%)$. Improvement in SPECT perfusion and infarct size reduction correlated with the number of $\mathrm{CD} 34^{+}$demonstrating mobility with stromal derived factor-1.

The apparent dose threshold of infused $\mathrm{CD} 34^{+}$was identified in post hoc analysis. In comparison to controls or those receiving low dose of cells, intracoronary infusion of $\geq 10$ million $\mathrm{CD} 4^{+}$cells was associated with significant improvement in myocardial perfusion measured by resting single-photon emission computed tomography (SPECT) and further quantified by a resting total severity score (RTSS). RTSS is a composite of the extent and severity of the perfusion defect assessed by SPECT, and serves as a potential index 
of cardiomyocyte viability that is validated to detect $\geq 10 \%$ difference on repeat measure [41]. Two previous studies that measured infarct region perfusion have observed similar changes $[6,42]$. Further supporting a CD $34^{+}$cell dose threshold was the concomitant trend toward improvement of LVEF among patients receiving $\geq 10$ million $\mathrm{CD} 4^{+}$cells, whereas patients receiving either 5 million $\mathrm{CD} 34^{+}$cells or the controls had no change. This was despite the fact that patients who received $\geq 10$ million $\mathrm{CD} 34^{+}$cells had larger infarct sizes and greater RTSS at baseline that would have predisposed them to a greater likelihood for adverse ventricular remodeling [43]. Moreover, the continued improvement in LVEF between 3 months and 6 months in patients who received $\geq 10$ million $\mathrm{CD} 34^{+}$cells, that was not seen in controls, suggests a progressive therapeutic effect that is consistent with recovery from hibernation and reduced apoptosis, a process that may be delayed for up to 6 months $[44,45]$.

4.5. Conclusion. We concluded that intracoronary infusion of selected bone marrow-derived $\mathrm{CD} 34^{+}$cells during the repair phase after STEMI is safe, and at a dose threshold of $\geq 10$ million $\mathrm{CD}_{3} 4^{+}$cells, it is associated with a significant improvement in perfusion that may limit deterioration in cardiac function.

\section{PreSERVE-AMI}

To followup our Phase I clinical trial with the bone marrowderived autologous $\mathrm{CD} 34^{+}$cell product, we have launched the PreSERVE-AMI trial, a Phase II multicenter, randomized, double-blind, placebo-controlled clinical trial to evaluate the efficacy and safety of AMR-001 at a dose of $\geq 10 \times 10^{6} \mathrm{CD} 34^{+}$ cells. The trial will enroll 160 patients with STEMI and reduced LVEF ( $<48 \%$ by cardiac magnetic resonance imaging 96 hours after stent placement). Subjects will be randomized $1: 1$ to treatment and placebo arms.

The primary aim of the PRESERVE-AMI is to demonstrate safety and determine the effect of intracoronary delivery of AMR-001 on myocardial perfusion by the resting total severity score (RTSS), as measured by gated SPECT MPI at baseline and 6 months. The secondary objectives are to assess the effect of AMR-001 on infarct size and cardiac function (LVEF), end systolic and end diastolic volumes, regional myocardial strain, and regional wall motion by CMR measured at baseline and at 6 month followup. Additionally, the impact of AMR-001 on quality of life (QOL) indices and clinical outcomes will be determined. QOL will be measured by the Kansas City Cardiomyopathy Questionnaire (KCCQ) and the Seattle Angina Questionnaire (SAQ) which will be administered at baseline, 6, and 12 months after randomization. Clinical outcomes, including MACE and change in NYHA class at 6 months, 12 months, 18 months, 2 years, and 3 years, will be monitored. MACE will be defined as cardiac death, hospitalization for worsening heart failure, and recurrent myocardial infarction. Clinical events such as ventricular arrhythmias requiring intervention, acute coronary syndrome (ACS), and coronary revascularization will be assessed as the same time points ( 6 months, 12 months,
18 months, 2 years, and 3 years). Additionally, total days alive and total days outside the hospital will be determined at 6 and 12 months. Tertiary objectives include characterizing the relationship between the quantity and quality of infused cells and perfusion, infarct size, LVEF, and clinical outcomes. We further aim to correlate initial predictors of outcomes including baseline LVEF, baseline infarct size, baseline RTSS score, number of prior AMI, IRA site, and time from STEMI to stent placement with changes in perfusion, infarct size, LV function, and clinical outcomes. Anticipated date of completion for the primary aim is January, 2013.

\section{Conclusion}

Intracoronary delivery of bone marrow-derived mononuclear cells by the "stop-flow technique" after acute STEMI has proven to be safe and is associated with modest improvement in LVEF $[6-8,10,13,15-17,20-23,25,29,30,39,46-48]$. Meta-analyses suggest that the benefit of cell therapy on postinfarct cardiac function is only apparent if cells are infused during the repair phase after STEMI, given in sufficient quantity, and with adequate mobility in an SDF-1 gradient $[29,31$, 47]; however, a major limitation has been the heterogeneity of unselected bone marrow mononuclear cells and the variability in cell doses employed. The CD34 surface marker identifies a population of cells within the bone marrow that exhibit regenerative characteristics, but only one study (in addition to our own) has examined the utility of $\mathrm{CD} 34^{+}$cell therapy, but at a relatively low cell dose $[25,49]$. Our recently published Phase I trial is the first prospective, dose-escalation controlled trial to determine if a dose threshold for effect exists. We demonstrated the apparent safety of harvesting $320 \mathrm{~mL}$ of autologous bone marrow from 5 to 8 days after STEMI, and successfully generated a sterile $\mathrm{CD} 34^{+}$stem cell product.

Whereas most unselected mononuclear cell therapy studies have infused doses of $\mathrm{CD} 34^{+}$cells that were consistent with our lowest dose cohort $[6,10,13,15-17,19-23,46]$, only one utilized doses comparable to the $\geq 10$ million cell cohorts in our study [13] (Table 1). Sustained improvement in LVEF was only observed in those receiving the higher cell doses, a finding also reported in recent meta-analyses $[7,8,15,29,50]$.

Natural mobilization of CD $34^{+}$cells coexpressing CXCR 4 that home to ischemic regions in response to an SDF-1 gradient induced by nuclear localization of hypoxia inducible factors after MI predicts prevention of cardiomyocyte loss and preservation of LVEF [31, 51]. Prevention of cardiomyocyte apoptosis and rescue from hibernation via paracrine effects (including AKt activation), as well as increased microvascular perfusion via neoangiogenesis, appear to underlie the restorative effects of infused $\mathrm{CD} 34^{+}$cells that appear to preserve cardiac function for up to four years in addition to lower adverse long-term event rate $[18,47,48,52]$.

One of the vital findings from our Phase I trial is that product potency (in terms of improvement in perfusion and LVEF) was related to the mobility of $\mathrm{CD} 34^{+}$cells in an SDF1 gradient, as previously reported $[6,29]$. Furthermore, cell mobility declined over time following bone marrow harvest, 
with a median $57 \%$ decrease between 24 and 48 hours after harvest and a further $11 \%$ decline by 72 hours. Administration of cells without delay after harvest may reduce the quantity of cells required for the therapeutic effect [53, 54]. Thus, the number of $\mathrm{CD}_{3}{ }^{+}$cells, their SDF-1 mobility, and the time from harvest to infusion are all factors that appear to determine potency of the cell product.

The discrepancy between positive animal studies and mixed clinical trials, as is often the case, requires further investigation by larger, well-controlled trials with adequate followup. The previous decade has taught us that bone marrow harvesting and intracoronary infusion of bone marrowderived $\mathrm{CD}_{3} 4^{+}$cells in doses up to 15 million cells during the repair phase after STEMI are feasible and safe. Yet, the interpretation of the benefit of $\mathrm{CD} 34^{+}$cell product as an ancillary treatment for acute STEMI is limited by the small number of studies, incomplete followup results, and significant variability in measures of cardiac function. The PreSERVE-AMI trial, that is currently underway, serves as an important "next step" toward addressing these issues and identifying a clinically viable cell product for the post-PCI management of STEMI.

\section{References}

[1] B. R. Brodie, T. D. Stuckey, C. J. Hansen et al., "Timing and mechanism of death determined clinically after primary angioplasty for acute myocardial infarction," American Journal of Cardiology, vol. 79, no. 12, pp. 1586-1591, 1997.

[2] M. Busk, M. Maeng, S. D. Kristensen et al., "Timing, causes, and predictors of death after three years' follow-up in the danish multicenter randomized study of fibrinolysis versus primary angioplasty in acute myocardial infarction (DANAMI-2) trial," American Journal of Cardiology, vol. 104, no. 2, pp. 210-215, 2009.

[3] A. Abbate, R. Bussani, G. G. L. Biondi-Zoccai et al., "Infarctrelated artery occlusion, tissue markers of ischaemia, and increased apoptosis in the peri-infarct viable myocardium," European Heart Journal, vol. 26, no. 19, pp. 2039-2045, 2005.

[4] B. G. Angeja, M. Gunda, S. A. Murphy et al., "TIMI myocardial perfusion grade and ST segment resolution: association with infarct size as assessed by single photon emission computed tomography imaging," Circulation, vol. 105, no. 3, pp. 282-285, 2002.

[5] M. A. Pfeffer, J. J. V. McMurray, E. J. Velazquez et al., "Valsartan, captopril, or both in myocardial infarction complicated by heart failure, left ventricular dysfunction, or both," The New England Journal of Medicine, vol. 349, no. 20, pp. 1893-1906, 2003.

[6] B. E. Strauer, M. Brehm, T. Zeus et al., "Repair of infarcted myocardium by autologous intracoronary mononuclear bone marrow cell transplantation in humans," Circulation, vol. 106, no. 15, pp. 1913-1918, 2002.

[7] A. Abdel-Latif, R. Bolli, I. M. Tleyjeh et al., "Adult bone marrowderived cells for cardiac repair: a systematic review and metaanalysis," Archives of Internal Medicine, vol. 167, no. 10, pp. 989997, 2007.

[8] M. J. Lipinski, G. G. L. Biondi-Zoccai, A. Abbate et al., "Impact of intracoronary cell therapy on left ventricular function in the setting of acute myocardial infarction. A collaborative systematic review and meta-analysis of controlled clinical trials,"
Journal of the American College of Cardiology, vol. 50, no. 18, pp. 1761-1767, 2007.

[9] E. Martin-Rendon, S. J. Brunskill, C. J. Hyde, S. J. Stanworth, A. Mathur, and S. M. Watt, "Autologous bone marrow stem cells to treat acute myocardial infarction: a systematic review," European Heart Journal, vol. 29, no. 15, pp. 1807-1818, 2008.

[10] B. Assmus, V. Schächinger, C. Teupe et al., "Transplantation of progenitor cells and regeneration enhancement in acute myocardial infarction (TOPCARE-AMI)," Circulation, vol. 106, no. 24, pp. 3009-3017, 2002.

[11] V. Schächinger, B. Assmus, M. B. Britten et al., "Transplantation of progenitor cells and regeneration enhancement in acute myocardial infarction: final one-year results of the TOPCAREAMI trial," Journal of the American College of Cardiology, vol. 44, no. 8, pp. 1690-1699, 2004.

[12] D. M. Leistner, U. Fischer-Rasokat, J. Honold et al., “. Transplantation of progenitor cells and regeneration enhancement in acute myocardial infarction (TOPCARE-AMI): final 5-year results suggest long-term safety and efficacy," Clinical Research in Cardiology, vol. 100, pp. 925-934, 2011.

[13] K. C. Wollert, G. P. Meyer, J. Lotz et al., "Intracoronary autologous bone-marrow cell transfer after myocardial infarction: the BOOST randomised controlled clinical trial," The Lancet, vol. 364, no. 9429, pp. 141-148, 2004.

[14] G. P. Meyer, K. C. Wollert, J. Lotz et al., "Intracoronary bone marrow cell transfer after myocardial infarction: 5-year followup from the randomized-controlled BOOST trial," European Heart Journal, vol. 30, no. 24, pp. 2978-2984, 2009.

[15] J. Ge, Y. Li, J. Qian et al., "Efficacy of emergent transcatheter transplantation of stem cells for treatment of acute myocardial infarction (TCT-STAMI)," Heart, vol. 92, no. 12, pp. 1764-1767, 2006.

[16] H. V. Huikuri, K. Kervinen, M. Niemelä et al., "Effects of intracoronary injection of mononuclear bone marrow cells on left ventricular function, arrhythmia risk profile, and restenosis after thrombolytic therapy of acute myocardial infarction," European Heart Journal, vol. 29, no. 22, pp. 2723-2732, 2008.

[17] V. Schachinger, S. Erbs, A. Elsasser et al., "Intracoronary bone marrow-derived progenitor cells in acute myocardial infarction," The New England Journal of Medicine, vol. 355, pp. 12101221, 2006.

[18] B. Assmus, A. Rolf, S. Erbs et al., "Clinical outcome 2 years after intracoronary administration of bone marrow-derived progenitor cells in acute myocardial infarction," Circulation, vol. 3, no. 1, pp. 89-96, 2010.

[19] A. Hirsch, R. Nijveldt, P. A. van der Vleuten et al., "Intracoronary infusion of mononuclear cells from bone marrow or peripheral blood compared with standard therapy in patients after acute myocardial infarction treated by primary percutaneous coronary intervention: results of the randomized controlled HEBE trial," European Heart Journal, vol. 32, no. 14, pp. 1736-1747, 2011.

[20] S. Janssens, C. Dubois, J. Bogaert et al., "Autologous bone marrow-derived stem-cell transfer in patients with ST-segment elevation myocardial infarction: double-blind, randomised controlled trial," The Lancet, vol. 367, no. 9505, pp. 113-121, 2006.

[21] K. Lunde, S. Solheim, S. Aakhus et al., "Intracoronary injection of mononuclear bone marrow cells in acute myocardial infarction," The New England Journal of Medicine, vol. 355, no. 12, pp. 1199-1209, 2006.

[22] J. H. Traverse, T. D. Henry, S. G. Ellis et al., "Effect of intracoronary delivery of autologous bone marrow mononuclear 
cells 2 to 3 weeks following acute myocardial infarction on left ventricular function: the LateTIME randomized trial.," Journal of the American Medical Association, vol. 306, pp. 2110-2119, 2011.

[23] J. H. Traverse, D. H. McKenna, K. Harvey et al., "Results of a phase 1, randomized, double-blind, placebo-controlled trial of bone marrow mononuclear stem cell administration in patients following ST-elevation myocardial infarction," American Heart Journal, vol. 160, no. 3, pp. 428-434, 2010.

[24] J. A. Miettinen, K. Ylitalo, P. Hedberg et al., "Determinants of functional recovery after myocardial infarction of patients treated with bone marrow-derived stem cells after thrombolytic therapy," Heart, vol. 96, no. 5, pp. 362-367, 2010.

[25] M. Tendera, W. Wojakowski, W. Ruyłło et al., "Intracoronary infusion of bone marrow-derived selected $\mathrm{CD} 34^{+} \mathrm{CXCR} 4^{+}$cells and non-selected mononuclear cells in patients with acute STEMI and reduced left ventricular ejection fraction: results of randomized, multicentre Myocardial Regeneration by Intracoronary Infusion of Selected Population of Stem Cells in Acute Myocardial Infarction (REGENT) Trial," European Heart Journal, vol. 30, no. 11, pp. 1313-1321, 2009.

[26] S. Fermas, F. Gonnet, A. Sutton et al., "Sulfated oligosaccharides (heparin and fucoidan) binding and dimerization of stromal cell-derived factor-1 (SDF-1/CXCL 12) are coupled as evidenced by affinity CE-MS analysis," Glycobiology, vol. 18, no. 12, pp. 1054-1064, 2008.

[27] M. Hofmann, K. C. Wollert, G. P. Meyer et al., "Monitoring of bone marrow cell homing into the infarcted human myocardium," Circulation, vol. 111, no. 17, pp. 2198-2202, 2005.

[28] W. Brenner, A. Aicher, T. Eckey et al., "111In-labeled CD34 ${ }^{+}$ hematopoietic progenitor cells in a rat myocardial infarction model," Journal of Nuclear Medicine, vol. 45, no. 3, pp. 512-518, 2004.

[29] M. B. Britten, N. D. Abolmaali, B. Assmus et al., "Infarct remodeling after intracoronary progenitor cell treatment in patients with acute myocardial infarction (TOPCARE-AMI): mechanistic insights from serial contrast-enhanced magnetic resonance imaging," Circulation, vol. 108, no. 18, pp. 2212-2218, 2003.

[30] A. Kawamoto, H. Iwasaki, K. Kusano et al., "CD34-positive cells exhibit increased potency and safety for therapeutic neovascularization after myocardial infarction compared with total mononuclear cells," Circulation, vol. 114, no. 20, pp. 2163-2169, 2006.

[31] F. H. Seeger, T. Tonn, N. Krzossok, A. M. Zeiher, and S. Dimmeler, "Cell isolation procedures matter: a comparison of different isolation protocols of bone marrow mononuclear cells used for cell therapy in patients with acute myocardial infarction," European Heart Journal, vol. 28, no. 6, pp. 766-772, 2007.

[32] S. Miraglia, W. Godfrey, A. H. Yin et al., "A novel fivetransmembrane hematopoietic stem cell antigen: isolation, characterization, and molecular cloning," Blood, vol. 90, no. 12, pp. 5013-5021, 1997.

[33] A. H. Yin, S. Miraglia, E. D. Zanjani et al., "AC133, a novel marker for human hematopoietic stem and progenitor cells," Blood, vol. 90, no. 12, pp. 5002-5012, 1997.

[34] S. Guo, Y. Cheng, Y. Ma, and X. Yang, "Endothelial progenitor cells derived from CD34 cells form cooperative vascular networks," Cellular Physiology and Biochemistry, vol. 26, no. 4-5, pp. 679-688, 2010.
[35] T. Asahara, T. Murohara, A. Sullivan et al., "Isolation of putative progenitor endothelial cells for angiogenesis," Science, vol. 275, no. 5302, pp. 964-967, 1997.

[36] E. T. H. Yeh, S. Zhang, H. D. Wu, M. Körbling, J. T. Willerson, and Z. Estrov, "Transdifferentiation of human peripheral blood $\mathrm{CD} 34^{+}$-enriched cell population Into cardiomyocytes, endothelial cells, and smooth muscle cells in vivo," Circulation, vol. 108, no. 17, pp. 2070-2073, 2003.

[37] M. Peichev, A. J. Naiyer, D. Pereira et al., "Expression of VEGFR2 and $\mathrm{AC} 133$ by circulating human $\mathrm{CD}^{+} 4^{+}$cells identifies a population of functional endothelial precursors," Blood, vol. 95, no. 3, pp. 952-958, 2000.

[38] C. Stamm, B. Westphal, H. D. Kleine et al., "Autologous bonemarrow stem-cell transplantation for myocardial regeneration," The Lancet, vol. 361, no. 9351, pp. 45-46, 2003.

[39] A. A. Quyyumi, E. K. Waller, J. Murrow et al., "CD34 ${ }^{+}$cell infusion after ST elevation myocardial infarction is associated with improved perfusion and is dose dependent," American Heart Journal, vol. 161, no. 1, pp. 98-105, 2011.

[40] D. Y. Jo, S. Rafii, T. Hamada, and M. A. S. Moore, "Chemotaxis of primitive hematopoietic cells in response to stromal cellderived factor-1," Journal of Clinical Investigation, vol. 105, no. 1, pp. 101-111, 2000.

[41] E. V. Garcia, T. L. Faber, C. D. Cooke, R. D. Folks, J. Chen, and C. Santana, "The increasing role of quantification in clinical nuclear cardiology: the Emory approach," Journal of Nuclear Cardiology, vol. 14, no. 4, pp. 420-432, 2007.

[42] M. Gyöngyösi, I. Lang, M. Dettke et al., "Combined delivery approach of bone marrow mononuclear stem cells early and late after myocardial infarction: the MYSTAR prospective, randomized study," Nature Clinical Practice Cardiovascular Medicine, vol. 6, no. 1, pp. 70-81, 2009.

[43] L. Spinelli, M. Petretta, W. Acampa et al., "Prognostic value of combined assessment of regional left ventricular function and myocardial perfusion by dobutamine and rest gated SPECT in patients with uncomplicated acute myocardial infarction," Journal of Nuclear Medicine, vol. 44, no. 7, pp. 1023-1029, 2003.

[44] O. Bondarenko, A. M. Beek, J. W. R. Twisk, C. A. Visser, and A. C. van Rossum, "Time course of functional recovery after revascularization of hibernating myocardium: a contrastenhanced cardiovascular magnetic resonance study," European Heart Journal, vol. 29, no. 16, pp. 2000-2005, 2008.

[45] L. Yan, D. E. Vatner, S. J. Kim et al., "Autophagy in chronically ischemic myocardium," Proceedings of the National Academy of Sciences of the United States of America, vol. 102, no. 39, pp. 13807-13812, 2005.

[46] F. Fernandez-Aviles, J. A. San Roman, J. Garcia-Frade et al., "Experimental and clinical regenerative capability of human bone marrow cells after myocardial infarction," Circulation Research, vol. 95, pp. 742-748, 2004.

[47] G. P. Meyer, K. C. Wollert, J. Lotz et al., "Intracoronary bone marrow cell transfer after myocardial infarction: eighteen months' follow-up data from the randomized, controlled BOOST (Bone marrow transfer to enhance ST-elevation infarct regeneration) trial," Circulation, vol. 113, no. 10, pp. 1287-1294, 2006.

[48] R. Uemura, M. Xu, N. Ahmad, and M. Ashraf, "Bone marrow stem cells prevent left ventricular remodeling of ischemic heart through paracrine signaling," Circulation Research, vol. 98, no. 11, pp. 1414-1421, 2006. 
[49] S. Dimmeler, J. Burchfield, and A. M. Zeiher, "Cell-based therapy of myocardial infarction," Arteriosclerosis, Thrombosis, and Vascular Biology, vol. 28, no. 2, pp. 208-216, 2008.

[50] J. Meluzín, S. Janoušek, J. Mayer et al., “Three-, 6-, and 12month results of autologous transplantation of mononuclear bone marrow cells in patients with acute myocardial infarction," International Journal of Cardiology, vol. 128, no. 2, pp. 185-192, 2008.

[51] A. M. Leone, S. Rutella, G. Bonanno et al., "Mobilization of bone marrow-derived stem cells after myocardial infarction and left ventricular function," European Heart Journal, vol. 26, no. 12, pp. 1196-1204, 2005.

[52] F. Cao, D. Sun, C. Li et al., "Long-term myocardial functional improvement after autologous bone marrow mononuclear cells transplantation in patients with ST-segment elevation myocardial infarction: 4 years follow-up," European Heart Journal, vol. 30, no. 16, pp. 1986-1994, 2009.

[53] S. J. Brunskill, C. J. Hyde, C. J. Doree, S. M. Watt, and E. MartinRendon, "Route of delivery and baseline left ventricular ejection fraction, key factors of bone-marrow-derived cell therapy for ischaemic heart disease," European Journal of Heart Failure, vol. 11, no. 9, pp. 887-896, 2009.

[54] K. Yao, R. Huang, A. Sun et al., "Repeated autologous bone marrow mononuclear cell therapy in patients with large myocardial infarction," European Journal of Heart Failure, vol. 11, no. 7, pp. 691-698, 2009.

[55] J. Bartunek, M. Vanderheyden, B. Vandekerckhove et al., "Intracoronary injection of CD133-positive enriched bone marrow progenitor cells promotes cardiac recovery after recent myocardial infarction: feasibility and safety," Circulation, vol. 112, no. 9, pp. I178-I183, 2005.

[56] J. Roncalli, F. Mouquet, C. Piot et al., "Intracoronary autologous mononucleated bone marrow cell infusion for acute myocardial infarction: Results of the randomized multicenter BONAMI trial," European Heart Journal, vol. 32, no. 14, pp. 1748-1757, 2011. 

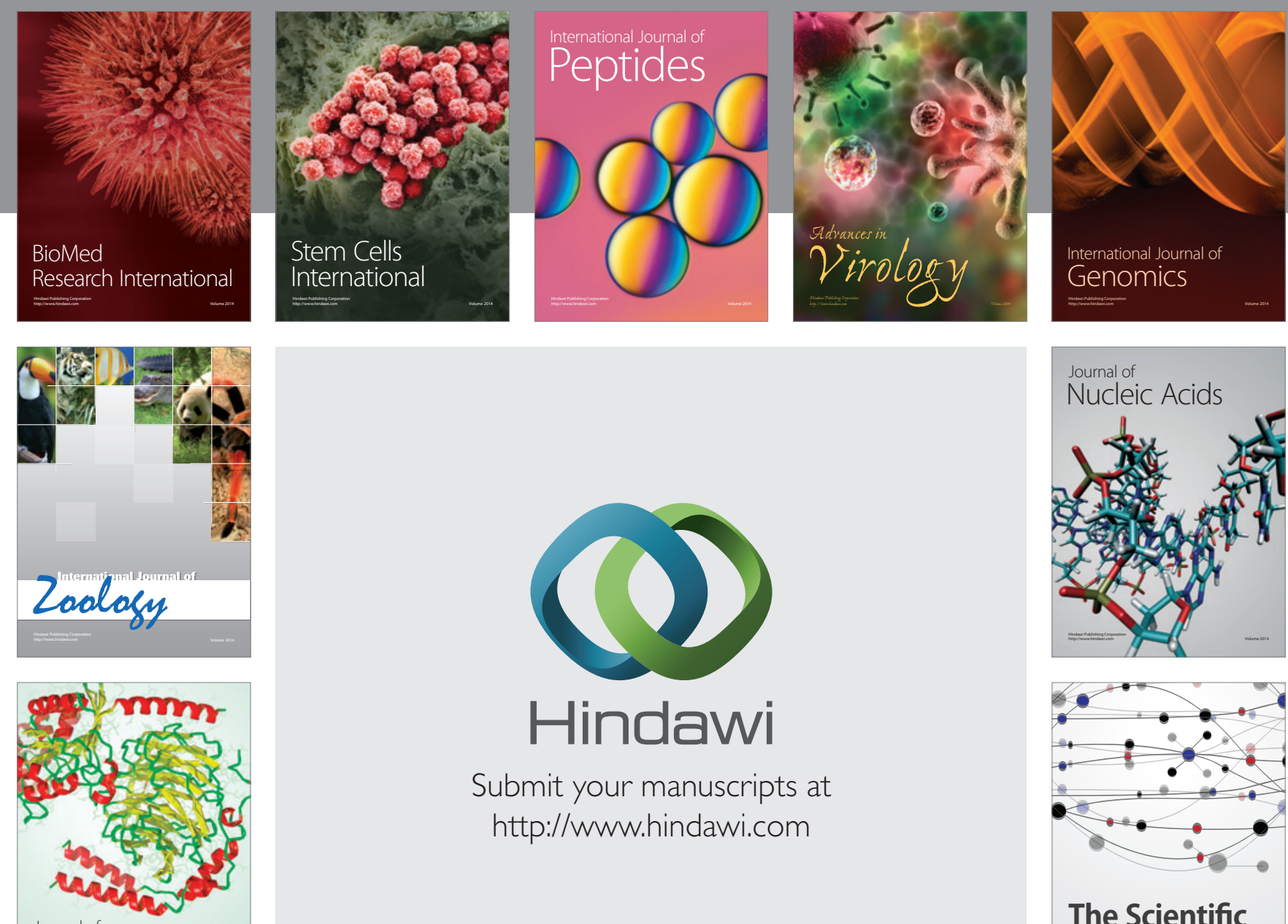

Submit your manuscripts at

http://www.hindawi.com

Journal of
Signal Transduction
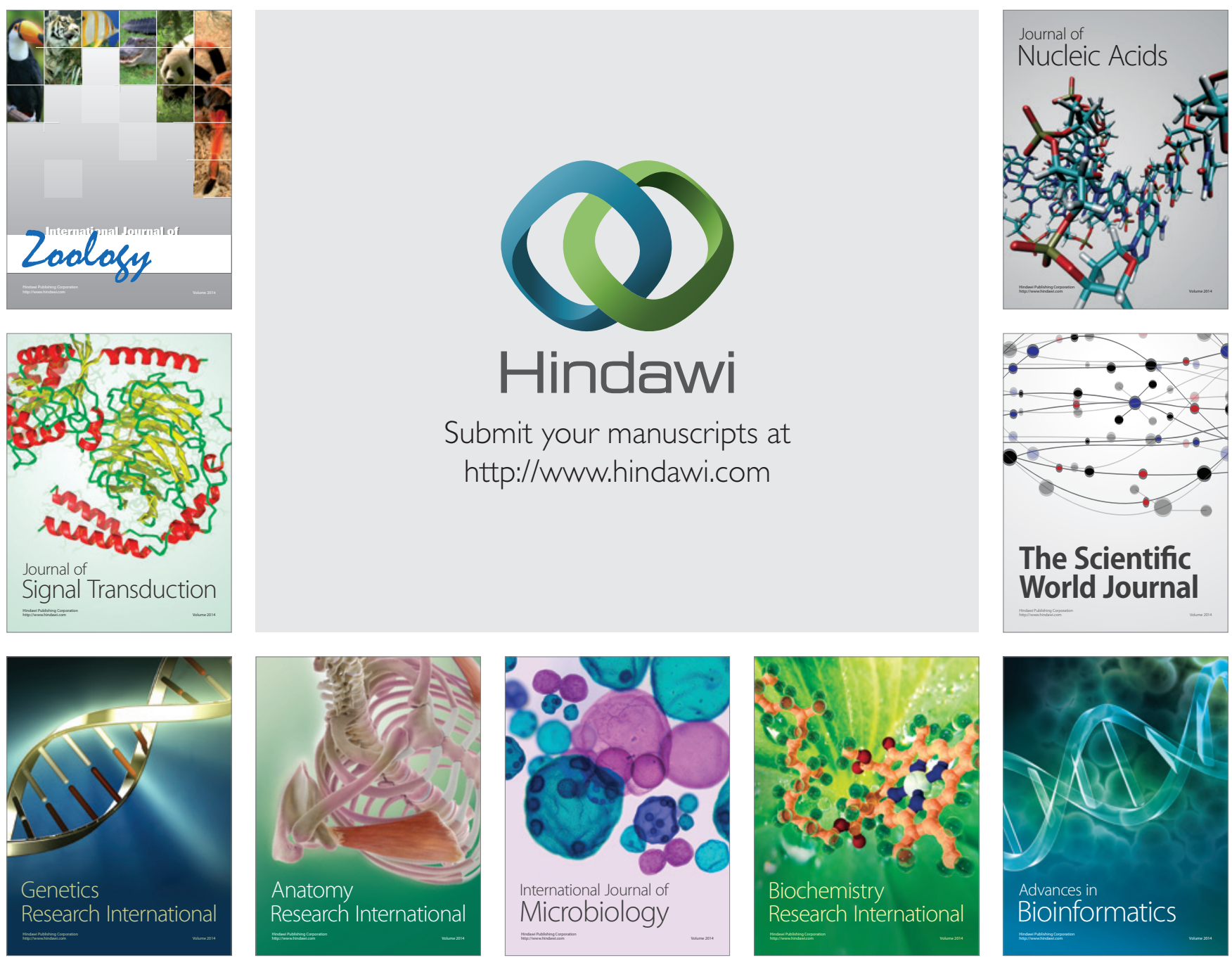

The Scientific World Journal
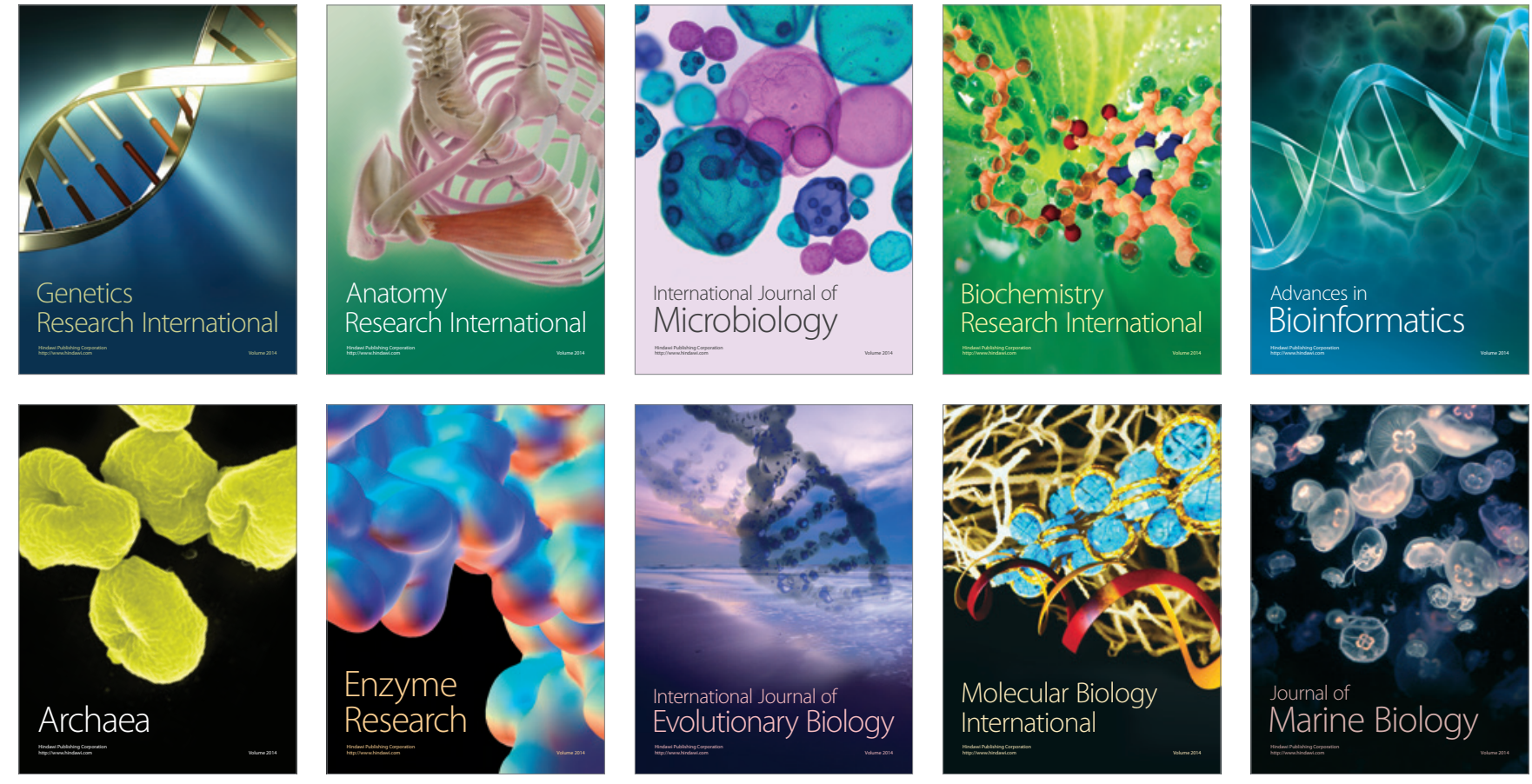